\title{
HANKISS ELEMÉR EMLÉKÉRE
}

\section{IN MEMORIAM ELEMÉR HANKISS}

\author{
Vitányi lván \\ az MTA doktora, szociológus, volt parlamenti képviselő \\ info@iask.hu
}

\begin{abstract}
ÖSSZEFOGLALÁS
Hankiss Elemér történelmi érdeme, hogy ő a nyugati szerzőkkel egy időben fogalmazta meg: elérkeztünk a "bizonytalanság korához", vagyis egy olyan állapothoz, amelynek nem tudjuk a folytatását. Elemér ezért fordult a filozófia felé, mert úgy látta, hogy általános emberi válsághoz érkeztünk, amelyet a gazdaság és a szociológia módszereivel nem lehet teljesen leírni. Az emberi gondolkodás a bizonyosságot kereste (ezt szolgálták és szolgálják a vallások is), de eljutottunk ahhoz a ponthoz, amelyben el kell fogadni a bizonytalanságot, illetve meg kell keresni a bizonytalanság és bizonyosság egyensúlyát. Összefoglalva: az utolsó negyven év szellemi életének egyik legkiválóbb képviselőjére emlékezünk, aki a legátfogóbb kérdéseket vetette fel.
\end{abstract}

\section{ABSTRACT}

It is Elemér Hankiss's historical merit that parallel with the Western authors he formulated the following: we have arrived at the 'age of uncertainty', in other words a state, continuation of which we do not know. Elemér therefore turned to philosophy as he recognized that we had come to a general human crisis that could not be described by the methods of economy and sociology. Human thought has always been seeking certainty (served in the past and present by religions as well) but we have come to a point when we need to accept uncertainty, and find a balance between certainty and uncertainty. To sum up, we now remember one of the most outstanding representatives of the intellectual life of the past forty years who raised the most cross-cutting issues.

Kulcsszavak: Hankiss, bizonytalanság, forradalom, szociológia

Keywords: Hankiss, uncertainty, revolution, sociology

Olyan tudósra és gondolkozóra emlékezünk most, aki az átélt társadalmi robbanások, változások és uralmak alatt az igazságot keresve mindig megőrizte a szellem szabadságát, következetességét és mélységét. Azon kevesek közé tartozott, 
akik tényleg eljutottak az igazsághoz. Mindezt nem azért tette, hogy önmagának szerezzen jólétet vagy hatalmat.

Jóleső érzés ez azoknak, akik barátai közé tartozhattak, mindig értettük egymást - még ha valamit másként láttunk is. Különösen nagyszerű idő volt, amit együtt tölthettünk a Szociológiai Intézetben. Mindig megtaláltuk a közös utat, és becsültük a másikat.

Tevékenysége hatalmas területet - vagy inkább területeket - fogott át. Kezdetben az irodalommal foglalkozott, azután a társadalommal, végül eljutott a filozófiához.

Amikor közelebbről megismerkedtünk, akkor tért át az irodalomról a társadalomra. Rögtön a közepét ragadta meg 1985-ben, a két Magyarország eszméjével. Ebben foglalta össze azokat az elméleteket, amelyeket a magyarok sorsán gondolkozó nagyjaink alkottak és vallottak Berzsenyitől Széchenyin és Kossuthon át Adyig és Bibóig, és a társadalom egy kisebbsége felfogta ennek igazságát. A másik a feudalizmus kötelmeit őrző többség. Már Hajnal István megmondta, hogy minden népnek olyan a kapitalizmusa, amilyen a feudalizmusa volt.

Elemér azonban nem maradt a puszta megállapításnál. Úgy vélte, hogy tenni is kell valamit. Persze nem kis akciókra, hanem a közgondolkodás megváltoztatására gondolt. Később, a rendszerváltás után ezért hirdette meg a „Találjuk ki Magyarországot" mozgalmat. Sajnos ekkor is kevesen értették, hogy ezt milyen széles körben gondolta.

Mivel nem talált elegendő megértésre, kiterjesztette ezt a gondolatot az egész világra. A kettős polgári-feudális társdalom maga a bizonytalanság. A világ különálló szférákra oszlott, a nyugati szociológusok szóhasználatával az észak-amerikai-nyugat-európai centrumra, a félperifériára és a perifériára. Mi természetesen a félperifériához tartozunk. Eddig azonban úgy látszott, hogy a bizonytalanság csak a félperifériát jellemzi (a periféria Samuel P. Huntington által jellemzett világairól most nem szólunk).

A legújabb időben azonban ez megváltozott. Az új fejlődés következtében a bizonytalanság megremegteti a félperifériát és a perifériát is.

Mi történt? Én ezt a világállapot változásával szoktam jellemezni. A fogalmat Arisztotelész találta ki, a kifejezést (Weltzustand) Hegel. Általában eddig - az ősi társadalom után - két világállapotot különböztettek meg különböző nevek alatt.

Például

Phüsis és nomosz - Arisztotelész

Status naturalis és status civilis - Spinosa, Rousseau

Hősi és polgári világállapot - Georg Wilhelm Hegel

Feudalizmus és kapitalizmus - Karl Marx

Folk és Urban Society - Robert Redfield

Gemeinschaft és Gesellschallft - Ferdinand Tönnies 
Az első világállapot kialakulását (az őstársadalom után) a „,prométheuszi” forradalom, azaz a tüz feltalálása hozta. Arisztotelész megmondta, hogy ez majd akkor változik meg, „ha az orsók maguktól fonnak”. Ez bekövetkezett. Ez lett a második prométheuszi forradalom. Az elmúlt évtizedeket pedig a harmadik jellemzi, az elektronika forradalma, és minden, ami hozzá kapcsolódik. Ennek felismerése igen széles körű a nyugati irodalomban, különböző nevek alatt: újkapitalizmus, turbókapitalizmus, posztindusztrializmus, posztmodernizmus.

De most még az átmenetnél tartunk, melynek egyik fö vonása a bizonytalanság. Ez jelenik meg a legújabb kor nyugati irodalmában. Jody Jensen erről szóló könyvében bemutatja, hogy miként. „Hibridizációnak” nevezik ezt a folyamatot (Jensen, 2014), még szemléletesebben „kaordinációnak”, amely egyesíti a káoszt és a rendet. A kaordináció megteremti annak lehetőségét, hogy az anyagi és szellemi javak eljussanak mindenkihez, de azokat a gátakat is, amelyek ezt megakadályozzák. A társadalmi következményeket én Immanuel Kant megállapításának továbbvitelével szeretem jellemezni. Ő a társadalom korabeli állapotát a „társiatlan társiassággal" jellemezte (Kant, 1926). Azt, teszem hozzá, hogy most eljutottunk a „társias társiatlansághoz”. Dick Howard pedig úgy fogalmazott, hogy a mai világállapotban a hatalom kettős szerelmi viszonyban van, egyrészt a demokráciával, másrészt az autokráciával. A nyilvánosság előtt összeházasodik az egyikkel, de a másikat szereti (Vitányi, 2014).

Hankiss Elemér történelmi érdeme, hogy ő a nyugati szerzőkkel egy időben fogalmazta ezt meg azzal, hogy elérkeztünk a „,bizonytalanság korához”, vagyis egy olyan állapothoz, amelynek nem tudjuk a folytatását. Munkacsoportunk egyetértett vele, Miszlivetz Ferenc ebben a szellemben jelentette meg az Eredeti válságfelhalmozás című tanulmánykötetet (Hankiss, 2009). Elemér ezért fordult a filozófia felé, mert úgy látta, hogy általános emberi válsághoz érkeztünk, amelyet a gazdaság és a szociológia módszereivel nem lehet teljesen leírni.

Az emberi gondolkodás a bizonyosságot kereste (ezt szolgálták és szolgálják a vallások is), de eljutottunk ahhoz a ponthoz, amelyben el kell fogadni a bizonytalanságot, illetve meg kell keresni a bizonytalanság és bizonyosság egyensúlyát.

Összefoglalva: az utolsó negyven év szellemi életének egyik legkiválóbb képviselőjére emlékezünk, aki a legátfogóbb kérdéseket vetette fel. Eltürték, de nem kapta meg azt a figyelmet, amit megérdemelt volna. A mi dolgunk, hogy folytassuk munkáját.

\section{IRODALOM}

Hankiss E. (2009): Társadalmi reformok. In: Miszlivetz F. (szerk.): Eredeti válságfelhalmozás. Szombathely-Budapest: Savaria University Press-MTA Politikai Tudományok Intézete 
Jensen, J. (2014): Globalizáció és új kormányzás. Budapest: MTA Társadalomtudományi Kutatóközpont Politikatudományi Intézet

Kant, I. (1926): Egy világpolgár gondolatai az emberiség egyetemes történetéröl. (ford. és bevez.: Sándor P.) (Európa könyvtár 1) Békéscsaba: Gesmey, http://mek.oszk.hu/04800/04821/04821. htm

Miszlivetz F. (szerk.) (2009): Eredeti válságfelhalmozás. Szombathely-Budapest: Savaria University Press-MTA Politikai Tudományok Intézete

Vitányi Iván (2014): A feudalizmus továbbélése a mai Magyarországon. Budapest: Kossuth Kiadó 